\title{
Print Culture in Exile: the Scottish Emigrant Reader in the Nineteenth Century ${ }^{\mathrm{I}}$
}

\author{
Bill Bell ${ }^{+}$
}

\begin{abstract}
After I had been there about ten or twelve days, it came into my thoughts that I should lose my reckoning of time for want of books and pen and ink, and should even forget the sabbath days from the working days; but to prevent this I cut with my knife upon a large post, in capital letters, and making it into a great cross I set it upon the shore where I first landed, viz. 'I came on shore here on 3oth Sept. $1659^{\prime}$. . . . among the many things which I brought out of the ship in the several voyages . . . . in particular, pens, ink, and paper, several parcels in the captain's, mate's, gunner's, and carpenter's keeping, three or four compasses, some mathematical instruments, dials, perspectives, charts, and books of navigation, all of which I huddled together, whether I might want them or no; also I found three very good Bibles which came to me in my cargo from England, and which I had pack'd up among my things; some Portugueze books also, and among them two or three popish prayer-books, and several other books, all of which I carefully secur'd.
\end{abstract}

Thus Defoe provides a carefully chosen catalogue of items essential for Crusoe's survival in a strange land. Perhaps predictably, among the principal items to be secured in his forays out to the wrecked vessel are the paraphernalia of science - charts, mathematical instruments, compasses; yet, as experience has taught him, just as important to personal definition and orientation in an unfamiliar landscape are the precious commodities of books, ink, and paper. Cultural memory is in exile contingent on - even reinforced by the continued practices of reading and writing. ${ }^{2}$

In the pages that follow I want to explore the relationship between the text and the experience of the exile. Although most of the following examples will relate to the Scottish diaspora in the nineteenth

+ Bill Bell is currently Professor of English Literature at the University of Edinburgh (Scotland). He is Co-director of the Centre for the History of the Book and is General Editor of History of the Book in Scotland. 
century, it is hoped that some of the larger questions addressed in this essay will suggest something of the contribution that the sociology of the text can begin to make towards what might be called a geography of communications. How exactly does the act of reading reinforce or challenge the cultural assumptions of the reader far from home? What, in more general terms, is the connection between the circulation of texts and the preservation of cultural identity under strange skies?

\section{Cultural Baggage}

One important aspect of Scotland's complex fate over the past three hundred years has been the scale of its mass migrations. From the first Highland Clearances in the eighteenth century to the assisted passages taken to Australia, Canada, and New Zealand in the twentieth, Scots have been on the move. By the early nineteenth century, the Scottish emigrant experience was one that was surrounded by print from before departure, throughout the journey, and, if anything, even more intensely so after arrival.

The great wave of nineteenth-century Scottish emigration was to occur at a time of conspicuously growing literacy, and so it was perhaps no coincidence that the causes of reading and emigration were to be constantly associated in the rhetoric of the period. 'After the daily labour of cultivating their new fields,' opined one Glasgow newspaper on the establishment of a settlers library in Upper Canada in I820, immigrants would now be able 'to retire and cultivate the best of fields, the human mind.'3 One Presbyterian minister advised his Australian-bound audience in $185 \mathrm{I}$ that they might profitably employ their time on the long voyage 'in reading what will improve your mind and your heart also ... in order to keep up with what is contemptuously styled the 'march of intellect.' ${ }^{4}$

In his I $848 \mathrm{Handbook}$ for New Zealand, E.G. Wakefield offered a detailed catalogue of reading matter that should be taken out by every 'good Colonist.' Under the general heading of 'BOOKS, MAPS, and ENGRAVINGS' Wakefield writes:

Every person who intends to adopt New Zealand as his future home will take care to supply himself with a good collection of these cheerful companions ... . Arrangements can easily be made after arrival and settlement in the colony for the formation of bookclubs, to be supplied periodically with such new publications as 
they may desire. Before starting, each family should arrange so as to receive regularly a file of some weekly London paper. Those which, like the Spectator, Examiner, and Athenaeum, contain full notices of literary, dramatic, and musical subjects, are the most satisfactory to a colonist.

That Wakefield was writing for the well-heeled cabin passenger is apparent from his recommendation that settlers should endeavour to take their own cattle, sheep, horses, and dogs. 'Good engravings will be a great ornament to the rooms of the colonist,' we read, selections of which can be 'seen at the British Museum, where there is a room set apart for them, open to any respectable person who applies for admittance.' Wakefield's intended audience was to be the exemplary carrier of high brow culture: 'The Colonist who is anxious to carry with him the memorials of the Fine Arts of the old world, may do so at comparatively little cost by purchasing at the British Museum casts in plaster of the antiques contained in that institution,' some of which could be easily 'conveyed to the colony ... . at little cost, affording very tasteful ornaments, whether for the public buildings or for the larger rooms of private residences. $^{\prime 5}$

The majority of settlement manuals were aimed not at the patrician 'colonist' but at the less well-to-do 'emigrant.' With the latter in mind, John Mathison of Aberdeen published in I 834 his Counsel for Emigrants to North America in which it was enthusiastically claimed that 'a very great number of works relating to Canada may be perused with advantage,' several of which could be purchased 'for less than a shilling, afford both information and amusement for the Emigrant, and are wonderful instances of the perfection to which cheap literature is brought. ${ }^{6}$ Reverend David McKenzie even went so far as to prescribe a healthy supply of cheap literature as an antidote to shipboard mischief:

Shipboard is your place of study. Consider every hour valuable, and diligently employ it in reading or meditation. It is want of employment that has been the most frequent occasion of quarrels among passengers on a long voyage .... In ancient times, those who went down to the sea in ships might no doubt have seen great wonders in the deep, for everything was then new, and before the art of printing . . . the information of mankind was very limited; but tempora mutuantur, - for neither the 'Penny Encyclopaedia' nor 'Chambers' Information for the People' was then known. ${ }^{7}$ 
So continued a series of concerted campaigns on the part of improvers, church organizations, and government agencies to promote overseas settlement, as tracts, pamphlets, newspaper articles, and posters poured from the presses in Glasgow, Edinburgh, and London. Although not unique to the nineteenth century, the circulation of advertisements publicizing the emigration cause was by midcentury at an all-time high. In I 85 I John Hill Burton remarked that in the most destitute parts of Britain 'one may read, stuck to the walls as decorations, the announcements of the Emigration Board. ${ }^{8}$ From the 1860 on, the production of promotional maps and guides was made a public priority, with agencies regularly providing reference rooms where prospective emigrants could read the literature freely, consult maps, and inspect registers of available property. Such advertising would become increasingly pervasive as the century progressed. Requesting in I 878 a subsidy for the publication of a newspaper for the promotion of emigration, Henry Simpson wrote to the Minister of Agriculture in terms explicitly connecting the causes of emigration and literacy: Canada, claimed Simpson, was 'almost a sealed book to the ordinary British farmer and small capitalist.' He need not have feared. Within a decade, a government directive had gone out requiring a map of Canada to be displayed in every British school, and a copy of the Hand Book for Settlers was presented to every pupil.

Perhaps the most successful means of publicizing emigration was in the 'letter home,' a format which appeared regularly in the popular press. These were usually anonymous accounts of life in the New World, written apparently for the benefit of the settler's family, and usually concluding with an exhortation to family and friends. So successful was the format to become that government officials, recognizing its effectiveness as propaganda, had by midcentury begun to solicit favourable accounts from the colonies. Malcolm Cameron, Minister of Agriculture, adopted the practice in his promotion of Canada in the 1850 , one of the most prolific suppliers being Alexander Somerville of Hamilton who for seventeen years (I 860-77) wrote for publication in the British press for a regular monthly fee of twenty dollars. ${ }^{9}$

Experience in the New World was, to say the least, heavily mediated in such documents. Predictably, many of those who read with delight glowing accounts of life in utopia would fail to recognize the place when they landed. Throughout the century, commentators were to remark on the disparity between emigrant experience and official representations of colonial life. A cartoon 
produced around i 820 entitled 'The Emigrant's Welcome to Canada' gives some indication of the level of indignation that many settlers felt about officially printed accounts of life in the New World. ${ }^{\text {Io }}$ The illustration - reproduced here - portrays the unfortunate newcomer as he steps off the boat into the welcoming arms of Jack Frost. While at his feet lies a bundle of settlement tracts that the unfortunate has in his horror dropped in the snow, emigrant guides go flying across the sky squawking 'Who's the goose now?' One of the most critical opponents of emigration propaganda was John McDonald, who wrote in I 82 I that 'it is by no means the ideal paradise which it is represented to be . . all the truth which has both been written and printed respecting Upper Canada, would not cover one-half of the lies which have been told.' ${ }^{\prime I}$ By midcentury the situation had not improved, causing one commentator to remark in I85 I on 'how large - how formidably large - are the elements of deception in the means of information which the emigrant has usually at hand. ${ }^{\prime 2}$ Such a sobering view of official print culture was often confirmed by nineteenth-century emigrants themselves, who frequently wrote bitterly home about how they had been misled by published information. 'It is absurd to think that all the Otago Journal is true,' wrote one disappointed emigre to his family in I 849. 'The gammon that the first comers wrote home,' commented another wryly, 'and which is come back here in the New Zealand journals, is dreadfully absurd exaggeration, nonsense, foolishness. ${ }^{\prime 3} 3$

Such propaganda was to generate widespread mistrust of the printed word among working class communities, causing the ScotsCanadian poet Alexander McLachlan to write bitterly:

And pious folks with their tracts, When our dens they enter in, They point to our shirtless backs, As the fruit of beer and gin ....

And they quote us texts to prove, That our hearts are hard as stone. ${ }^{\mathrm{I} 4}$

As one witness to the Select Committee on Postage reported in I 839, as a result of their increased scepticism about the reliability of officially produced documents, the poor had learned to privilege the private letter over the printed text as a source of information. In his study of nineteenth-century immigrant communities in Australia, Richard Broome observes how compensation was found 


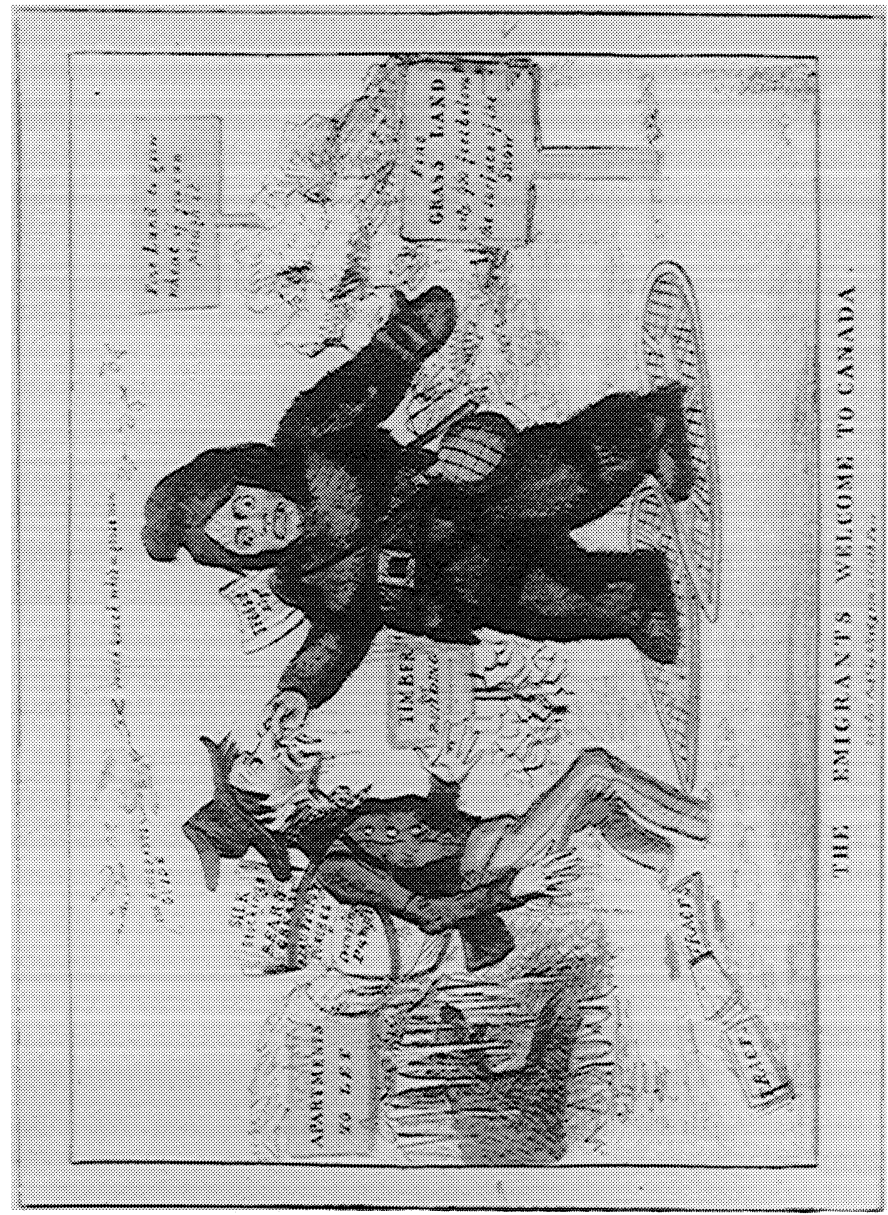

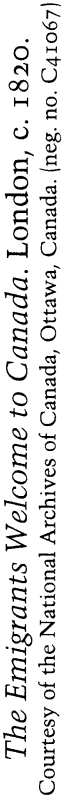


by 'many colonists [who] travelled "home" in their thoughts. Thousands of wax-sealed letters crossed the sea . . . . precious lifelines between the old and new worlds.' ${ }^{15}$ In settler society, the letter from home could function as a community event as well as a private mode of communication, these precious documents often being passed from hand to hand, and routinely read aloud. In a world of dubious print, the correspondence between communities of friends and relatives was one of the most important means of maintaining a sense of authentic collective identity for the nineteenth-century settler.

Another way in which the individual could participate in familiar cultural networks after arrival was through the casual flow of unofficial print that was regularly sent out and back from the colonies, between family members and friends. Perhaps the best source of information about actual reading conditions on the nineteenth-century frontier is to be found not in the printed record but in the accounts left by settlers themselves in diaries and letters, many of which contain requests for reading matter from home. Local newspapers seem to have been particularly desirable not simply because they were relatively cheap to procure - although this was clearly a factor - but also because the newspaper represented a more immediate and tangible link with the home community. As Ross Harvey observes in his study of the New Zealand press in this period, the newspaper from home carried intense symbolic significance for the immigrant, not least in its power to evoke nostalgia for the culturally familiar. ${ }^{16}$ Thus we find the Toronto farmer James Reid writing to an Ayrshire friend in I 849, ${ }^{\mathrm{I}}$ 'I employ a great deal of my time reading. I have the whole of Thomas Dicks works, Dr. Chalmers, and Stackhouses History of the Bible and ... a number of inferior works. Please send me a newspaper or two in the Spring with an account of the ploughing matches and you will oblige an old friend. ${ }^{17}$

Despite the optimism of the experts, with a severely limited cargo allowance (a mere twenty cubic feet per passenger bound for Australia in the I850s), with houses to build and furnish, children to feed and clothe, and crops to plant, it is unlikely that many books beyond Bibles and catechisms - perhaps the odd volume of Pilgrim's Progress - would have found their way on the voyage. Those that did would most likely have been locked up tight in the hold throughout the journey. As one official source advised Montreal passengers in 1842 'the baggage of emigrants should consist only of their wearing apparel, with such bedding and utensils for cooking 
as may be required on the voyage ... any articles not to be used at sea, ought to be packed in water-tight cases, or trunks, not exceeding 80 or 90 pounds in weight. ${ }^{18} \mathrm{~A}$ further prohibition was the high duty payable on the importation of printed matter, a luxury which, it was often assumed, the steerage passenger could well do without. As the British Vice-Consul and Agent of the Canada Land Company warned would-be emigrants in I 833 , they would 'have to pay duties on little which they commonly have - say ... linen ... tools ... books.'

In response to such privation, several philanthropic organizations were to offer financial assistance for the subsidy of reading on board emigrant vessels, even in some cases offering to offset the high cost of importation. In I82I, the Committee on Emigration from the West of Scotland to the Settlements in Upper Canada resolved at their Glasgow meeting:

that the luggage of the Emigrants be restricted to their body and bed-clothes, pots and pans, a small assortment of crockery ware, and a few articles necessary for their own immediate use; and that no furniture be carried out, such as chests of drawers, clock-cases, bed steads, chairs, tables, or washing-tubs, unless the emigrants are in sufficient circumstances to pay for the transport of the same from Quebec to the place of settlement; but the books which they may have, as their private library, may be allowed; and the whole must be closely packed in small and sufficient chests, boxes, or bagging. ${ }^{\text {I9 }}$

With private libraries (such as they were) packed away, steerage passengers would sometimes be invited to entertain themselves with devotional and improving reading matter issued on board by emigrant societies and church organizations. By the first half of the nineteenth century, such arrangements appear to have been common on emigrant vessels. John Fraser of Glasgow records in his Canada bound diary for 1837, 'Mr John M. Hamilton and myself, by request of the Captn. distributed religious tracts among the Passengers, many of whom could not read, those who could accepted them with avidity. ${ }^{20}$ In some instances the distribution of shipboard reading matter was more carefully orchestrated in the form of lending libraries. Upon his arrival in Sydney in February I 850, schoolmaster Richard Murphy was pleased to report that 'the box of books granted by the Committee of the Emigrant School Fund was found very serviceable, was well read by the emigrants, and distributed to them on leaving. ${ }^{21}$ In I 848 the Otago Association similarly acknowledged a liberal bequest of books donated by various civic 
organizations for the founding of the Dunedin community, among them a copy of the Encyclopaedia Britannica contributed by the publisher and Lord Provost of Edinburgh, Adam Black. The library, reported the Association with unrestrained pride, was 'despatched with parties of emigrants in three ships, to whom doubtless they have been a profitable source of amusement and instruction at sea. ${ }^{22}$ Despite these official attempts to alleviate the situation, the relative scarcity of shipboard reading matter continued to be a problem, even on vessels where some provision had been made (for all of the optimistic committee reports, we know that only one book per week among six adults was in actuality provided on board the three Otago vessels). ${ }^{23}$ The most compelling evidence of attempts to compensate for the paucity of shipboard entertainment are perhaps to be found in the many letters and journal entries left by emigrés themselves. As one traveller noted in his shipboard diary 'tho' the forgoing pages of this journal may not be particularly important or interesting to any, yet they may help to while away the tedium of the hour, while nothing better can be had. ${ }^{24}$

\section{Transplanted Networks}

According to Benedict Anderson, the imagination of cultural synchronicity across vast distances was to a great extent made possible in the nineteenth century through the mediation of what Anderson calls 'print-capitalism':

It became conceivable to dwell on the Peruvian altiplano, on the pampas of Argentina, or the harbours of ' $\mathrm{New}^{\prime}$ England, and yet feel connected to certain regions or communities, thousands of miles away, in England or the Iberian peninsula. One could be fully aware of a shared language and a religious faith (to varying degrees), customs and traditions, without any great expectation of meeting one's partners. $^{25}$

Thus Anderson situates commercial textuality at the centre of the colonial project, mediating and defining a common imperial identity for geographically disparate groups. Without print, so the argument goes, the colonial project would not to the same extent have been possible. In her recent survey of Colonial and Postcolonial Literature, Elleke Boehmer argues similarly for the importance of what she calls the 'textuality of empire': 
At its height the British Empire was a vast communications network ... . [and] at least in part, a textual exercise ... . The Empire in its heyday was conceived and maintained in an array of writings - political treatises, diaries, acts, and edicts, administrative records and gazetteers, missionaries' reports, notebooks, memoirs, popular verse, government briefs, letters "home" and letters back to settlers.

Through such communications networks, argues Boehmer, 'colonization seeded across widely separate and vastly different territories cultural symbols which exhibited a remarkable synonymity' ${ }^{\prime 26}$

Helpful as they are in defining the mechanics of imperial ideology, such totalizing perspectives do little in the end to account for the actuality of settlement life. To pay due attention to the specificity of emigrant experience is to be sceptical of the very 'synonymity' which is bound up with the homogenizing rhetoric of Empire. Furthermore, analyses that unproblematically deploy the opposition of colonizer/colonized avoid at their peril questions of race, religion, gender, and class difference between and within settler communities, close examinations of which militate against the very idea of a homogenous 'British' colonial practice. Immense diversity can alone be seen in the multiple versions of Scottishness that were transplanted in a myriad of different complexions and intensities across the world, as variations of class, language, and religion to be found at home were time and again replicated overseas, often in exaggerated forms. Whenever we think of the Scottish immigrant community, therefore, it must always be with the awareness that we are not speaking of a single cultural unit, but a whole range of regional, religious, and economic groups with their own distinct (though sometimes related) cultural networks.

In his study of the Irish in America, Charles Tilly has coined the phrase 'transplanted networks' as one way of explaining the heterogeneity of immigrant experience. Variant identities in a colonial context, argues Tilly, are not the result of monolithic ideologies, nor are they spontaneous social constructs, but historic consequences of simultaneously existing information networks which replicate and modify themselves in new geo-political contexts. Offering an alternative to conventional models of immigration history in what he calls 'network structure', Tilly argues that 'instead of a series of individual transformations in the direction of a dominant . . . culture, migration involves negotiation of new relationships both within and across networks. Instead of individual 
status-striving, collective efforts to cope. Instead of wholesale transplantation, selective re-creation of social ties. ${ }^{27}$

One way in which social ties were selectively recreated within settler communities was through the extension of familiar textual networks. 'For many networks,' argues Tilly, 'North America simply represented one more extension of circuits that had long served the same purpose within Europe' ${ }^{28}$ It was in the area of religion in particular that a devotion to cultural difference was most conspicuously in evidence, as throughout the nineteenth century vigorous campaigns were launched by missionary organizations to build infrastructures that would allow Scots, wherever they were, to resist assimilation through the practice of religion on their own familiar terms. ${ }^{29}$ Unsurprisingly, it was in this area that Scottish settlers appear to have had the most clearly defined textual requirements. ${ }^{30}$

In the battles for the hearts and minds of displaced congregations, the printed word was often seen as an important point of stasis and authority in an otherwise unpredictable and unfamiliar environment. Some of the best efforts to ecumenise frontier religion were to be met, at best, with indifference; at worse, with outright antagonism. Reverend James Nisbet, who travelled on behalf of the Canada Sabbath School Union in I 848, met resistance from Anglicans and Methodists who, reported Nisbet, 'objected to our books as not going far enough in stating the truth respecting the Sacraments'. ${ }^{3 \mathrm{I}}$ Presbyterians could be just as intractable, if not more so. In an effort to maintain religious and cultural separatism, the Biblical verse 'ye are a peculiar people' was regularly invoked by Scottish clergy in missionary sermons and tracts. One of the most zealous of these was John Dunmore Lang (famous for his use of the phrase 'there's nae folk like our ain folk') who was responsible for the resettlement of thousands of Highlanders in Australia from the I83os on. Lang's scheme proceeded on the assumption that their religious beliefs, combined with their reliance on Gaelic, would make his charges impervious to the corrupting influence of convicts and Catholics, providing an antidote to the moral plague that Lang believed transportation had spread in the New World. Their language itself would place them, in his words, 'beyond the reach of contamination'. ${ }^{32}$

One of the most dramatic examples of this kind of socio-religious separatism at work is to be found in the New Zealand settlement of Waipu, involving the double migration of the followers of the Reverend Norman McLoud, who had settled around St. Anne's, 
Nova Scotia, in the first half of the nineteenth century and who were to move en masse with their leader to North-West New Zealand on six ships between I 855 and I859. At a time when the colonial government was implementing its policy of so-called 'contiguity and concentration,' its geographical isolation appears to have been what most commended Waipu to McLoud and his nine hundred followers. In her ethnographic study of the double migration, Maureen Molloy stresses the importance of the connection between isolation and kinship. 'The repeated emphasis on isolation from strangers', observes Molloy, suggests that the desire of the Nova Scotian settlers 'to maintain a geographical boundary between themselves and others was strong'. Before arrival, the Normanites had arranged for the purchase of adjoining tracts of land in order to ensure that no contiguous blocks would be inhabited by non-Nova Scotians, in their words 'to prevent any strangers from being placed among them' ${ }^{33}$ It is this very isolation that today makes Waipu most intriguing from the point of view of the historian, providing, as it does, an interesting laboratory in which to try a range of cultural questions, not least those relating to reading habits and the circulation of texts in exile.

Among the farm implements, kitchen utensils, photographs, and letters, today's visitor to the Waipu settlers museum can find a relatively small but significant library of over a hundred volumes, which taken together offer a fascinating window on the book owning and reading habits of a small community over the better part of a century. Most revealing are the precious twice-travelled books that a number of emigrants were to bring with them from Scotland to Nova Scotia and thence on to New Zealand in the 1850 os. The fly leaf of one Gaelic Psalter intimates that it was 'used by Rev Norman McLeod, in his churches in Scotland, Nova Scotia, and Waipu, and by the pioneers in their homes for Family Worship'. Prior to his departure for Nova Scotia in I 845 Colin McDonald, a thirty-five-year-old native of Gourock, purchased a Gaelic New Testament printed in Edinburgh two years earlier. The same book accompanied him to New Zealand when he re-emigrated over a decade later.

Other members of the community were to acquire books during their sojourn in North America. In June I 846 Neil Campbell purchased a I6th edition of Crosby's Key to Walkinghame's Tutor's Assistant (I 843), printed by Wilson \& Co in York, Upper Canada, and was later to take it with him on board the Spray bound for Waipu in I 856. Daniel Robertson brought with him a family Bible printed 
in New Brunswick that he had acquired while he was living in Churchville, Nova Scotia. Norman McLennan had in I847 purchased a brand new copy of Joseph Worcester's Dictionary (printed in Boston that same year) while he was living in Warcham, Massachussetts. This too came to Northland in I 855 .

Books seem to have served important social as well as purely religious functions at Waipu, and Scottish texts in general appear to have had high cultural significance. In I 884, an Edinburgh edition of The Poetic Works of Robert Burns was presented to the second generation settler Christine McMillan by her prospective husband. Burns has always held strong symbolic importance for the emigrant Scot, and we can see in such gestures just how intimately bound up with the reading experience are expressions of kinship and ethnicity. ${ }^{34}$ At a time when many New World Scots were happily participating in hybrid literary cultures, what is perhaps most remarkable is the lengths to which the Waipu settlers and their descendants went to acquire Scottish imprints well into the twentieth century, at a time when North American and Australian versions were far easier to obtain. ${ }^{35}$ Of the Scottish imprints found at Waipu, almost half appear to have been purchased after settlement. If anything there appears to have been an increased bias towards texts of Scottish origin as time passed. At a meeting of the Waipu Library Committee in November I 890 'after some discussion, in regard of getting new Books .... . it was proposed that we send to Edin. for books to the value of $\mathfrak{E} 6$ '. In the following May 'correspondence \& receipts in regard to Books received from Home was read . . . it was proposed that we pay half the expenses of getting the Books out from Home'. In spite of two migrations - one might even say because of two migrations - tangible links with a home many had never seen became increasingly important, and reading was one of the symbolic acts that made this possible.

In her study of reading practices in the American republic, Cathy Davidson - following Rolf Engelsing's account of the transition from an 'intensive' to an 'extensive' relationship with print - has argued that by the end of the eighteenth century 'the quality and the nature of reading was changing'. Instead of a highly concentrated and meditative relationship with the text, principally through the Bible, sermons, and tracts, secularization and the widening availability of books had transformed the way that print was consumed. Davidson's account of the move from 'intensive' to 'extensive' reading patterns is one based on a belief in the more general transformation of political subjects into an active republican citizenry, 
and so the argument goes from 'elementary to advanced literateness'. 'The whole mentality of reading was changing', argues Davidson, 'and, clearly, the Bible and the Psalter no longer occupied the singular place they once had in the life of the community or of the individual reader'. ${ }^{36}$

Such wholesale transitions do not necessarily apply to the many isolated settlements across nineteenth-century North America where the Bible and Catechism still held a privileged place in the daily life of the reading community, and where the preservation of religious values was often itself regarded as a deliberate act of opposition to the larger world beyond. In his account of the Normanite settlement in I840s Nova Scotia, Neil Robinson remarks that 'in this conservative community ... reading occupied a different role from that it enjoys today. The Bible provided an inexhaustible well of drama, poetry, and spiritual inspiration .... Even when the reader had memorized whole sections of them, he would return, in his rare intervals of leisure, to the comfort of the written word'. As society was becoming more generally secularized, so an active resistance to the dominant culture was exercised by a number of ethno-religious groups in the New World, influenced by and, in turn, necessitating an intense relationship with the authoritative text.

By the late nineteenth century, however, Scottish communities in industrial conurbations like Montreal, Sydney, and New York were becoming by degrees secularized and culturally integrated. Over time, the majority of settlers and their descendants - particularly urban dwellers - would take their places in increasingly hybrid print cultures, retaining only nominal links with home through letters, newspapers, and books. Yet myths of national origin have a tendency to gain potency in proportion to the extent that a community feels its ethnicity threatened, and it is at the very moment when Scots are becoming increasingly assimilated religiously, racially, socially - that signifying practices emerge which serve to renew a sense of cultural difference. As Carl Klink observes in the context of Canadian literary culture, it was at the point of assimilation that a new form of Scottish writing was to emerge which was 'a reflection, in part, of a consciousness of race - racial origins, potentialities, and disasters - a feeling which became increasingly intense towards the end of the century ${ }^{\prime}{ }^{37}$ It is perhaps no coincidence that the great wave of global Caledonian activity occurs at exactly this moment. Witness the number of colonial editions of Burns that were produced from the 1870 on, 
as well as the volume of Scots vernacular poetry being written and read by second and subsequent generation immigrants who had never in their lives spoken the language. Yet the establishment of Highland games, clan gatherings, Scottish Rite temples, St. Andrews and Burns societies, from Waipu to Hamilton, Melbourne to Johannesburg, often taken as evidence of a cultural confidence, might rather be the most obvious consequence of a crisis of identity, not so much a celebration as a reaction to the threat posed by emergent nationalisms.

It is nevertheless those who can readily assimilate both culturally and economically that make the greatest success stories in the birth of a nation. Wherever there is money to be made, Robert Louis Stevenson once commented, there you will find Scots, and this was perhaps never truer than in Canada. As early as I 806, Judge Robert Thorpe could complain about an already established 'chain' of 'Scotch pedlars ... . linked from Halifax to Quebec, Montreal, Kingston, York, Niagara, \& so on into Detroit' so powerful that it was proving detrimental to competitive trade..$^{38}$ The tendency of Scots to consolidation in business dealings was as true in the book trade as in other areas of commerce. 'Down to I900', as one historian has observed, 'the Canadian village outside Quebec typically had its leading Kirk and minister, its Scottish schoolmaster, and its Scottish-derived editor and printer' ${ }^{39}$ Though there was nothing unusually Scottish about his stock, in establishing his Quebec City business in 1795 with apprentices from Glasgow, John Neilson was not the last to set up shop with labour and equipment imported from home. Many of the dominant figures in the Canadian book trade before and after Confederation would continue to be part of a powerful network of booksellers, printers, and publishers who had learned their professions in Aberdeen, Glasgow, and Edinburgh and who kept themselves supplied by drawing on their trade connections at home and abroad: Armour \& Ramsay of Montreal, Adam Stevenson \& Company of Toronto, James Dawson of Pictou, and, of course, William Lyon McKenzie, to name but a few.

The role that the production, circulation, and reception of texts has had to play in the formation and preservation of cultural networks should be self-evident. Until recently, however, the study of emigration history has developed in relative isolation from a history of communications. And although book history had done much to analyse patterns of production and consumption, even where terms such as 'trade', 'distribution', and 'circulation' have been used, the tendency has been to regard the market from the 
perspective of either manufacturer or consumer, rarely in terms of the larger geographical networks in which such transactions take place.

Over three decades ago, Wilfred Egglestone challenged the literary historian 'to trace the importance of . . . books in pioneer North America', arguing that no credible account of early Canadian culture would be possible until adequate attention had been paid to 'the reading public, the educational apparatus, the libraries, the printing presses, the publishers, the bookshops' that had made it all possible. ${ }^{40}$ Thanks to the recent efforts of a number of scholars, this task has begun. ${ }^{4^{\mathrm{I}}}$ Much work remains. This article has offered no more than a brief resumé - by no means complete - of a number of areas that will reward further, more careful enquiry. To recognize the importance of textual communication to the emergence of societies is to begin to realize some of the ways in which the history of the book is now beginning to inform the history of culture.

\section{RÉSUMÉ}

Cet article présente une introduction générale sur le thème des lecteurs coloniaux écossais, en affirmant qu'au dix-neuvième siècle la mémoire culturelle était souvent dépendente des pratiques soutenues de la lecture et de l'écriture. En plaidant pour une relation intime entre les pratiques de lecture et l'expérience de l'exil, l'auteur cherche à démontrer dans quelle mesure l'identité culturelle écossaise fut renforcée, et à l'occasion remise en question, par la circulation des textes dans des pays étrangers. En examinant l'importance de la production textuelle vis-à-vis l'augmentation de l'émigration au début du dix-neuvième siècle, la première partie ('L'environnement textuel') identifie une gamme de pratiques textuelles les plus courantes, de la propagande officielle gouvernementale et religieuse à celles, plus informelles, de lecture de bord et de rédaction de journaux particuliers et de lettres. La deuxième partie ('Réseaux transplantés') porte sur l'expérience de l'émigrant après son établissement et conteste certaines théories post-coloniales qui généralisent les exemples sans se préoccuper de la spécificité de l'expérience de peuplement. La communauté à Waipu, colonisée par des Écossais de la Nouvelle-Ecosse dans les années I85o, est présentée ici comme un cas-type dans le but de décrire les façons dont les livres furent utilisés pour conserver un étonnant sens d'identité culturelle en 
exil. L'article se termine avec la reconnaissance que, vers la fin du dix-neuvième siècle, la plupart des communautés écossaises en Australie, au Canada et en Nouvelle-Zélande étaient amenées à participer à des cultures de l'imprimé de plus en plus hybrides et sécularisées.

A cette époque, l'augmentation de la nostalgie pour le pays d'origine, évidente par la formation de sociétés et de clubs écossais à travers les différents nouveaux mondes, est attribuable plus à une sensation de crise culturelle amenée par ce processus d'hybridation qu'à la confiance culturelle à laquelle on l'attribue souvent. Dans son ensemble, l'article souligne l'importance du développement de la géographie des communications et reconnait que l'histoire du livre contribue déjà à la connaissance de l'histoire culturelle.

NOTES

I This paper was originally presented as a keynote address at the inaugural History of the Book in Canada conference, National Library of Canada, Ottawa, May 24, I997. I am grateful to the Carnegie Trust and The Faculty of Arts of The University of Edinburgh without whose support aspects of this research would not have been possible.

2 Apart from the Bible and Pilgrim's Progress, Robinson Crusoe was throughout the nineteenth century among the most frequently recommended reading matter for the prospective emigrant, the protagonist himself representing the embodiment of Protestant self-reliance. 'To teach the mechanic the use of inventive resources in an emigration field,' wrote one Scottish writer in the I 850 , 'there could be no better book than Robinson Crusoe'. [John Hill Burton, The Emigrant's Manual (Edinburgh: Chambers, I850), 23.] A decade earlier, James Brown had even referred unironically to Scottish settlers in British North America as 'Canadian Crusoes'.

3 Robert Lamond, A Narrative of the Rise and Progress of Emigration from the Counties of Lanark and Renfrew to the New Settlements in Upper Canada (Glasgow: Chalmers \& Collins, I82 I), I4.

4 David MacKenzie, Ten Years in Australia (London: William Orr, r85 I), r52-3.

5 Quoted in Life in a Young Colony: Selections from Early New Zealand Writing, Cherry A. Hankin ed. (Christchurch: Whitcoulls, I98I), 30-40.

6 John Mathison, Counsel for Emigrants and Interesting Information (Aberdeen: Mathison, $\mathrm{I} 834$ ), $\mathrm{x}$.

7 MacKenzie, Ten Years in Australia, I 52-3.

8 Burton, Emigrant's Manual, I3-I4.

9 Eventually, professional letter writers were dispatched for the express purpose of providing sympathetic accounts for the home reader. One of these, Peter 
O'Leary, was sent to Canada in I 884 for 'the purpose of writing letters to the English papers' about favourable conditions in the North-West. For a detailed discussion of emigration propaganda in a Canadian context, see chapter three, 'Wooing the Emigrant', in Norman MacDonald, Canada: Immigration and Colonization I84I-I903 (Toronto: Macmillan I966), 30-48.

ro 'The Emigrant's Welcome to Canada' (c. I820), National Archives of Canada, c41067.

II John McDonald, Voyage to Quebec and Journey from thence to New Lanark in Upper Canada (Edinburgh: Andrew Jack, I82I), I2.

I2 Burton, Emigrant's Manual, I I-I 2.

I 3 Emigrants' Letters: Being a Collection of Recent Communications from Settlers in the British Colonies (London: Trelawney Saunders, I 850), 92.

I4 Alexander McLachlan, The Emigrant and Other Poems (Toronto: Rollo \& Adam, I 861), 202.

I5 Richard Broome, The Victorians Arriving (McMahons Point, Nsw: 1984), 36-37. See also Jane E. Harrison, Until Next Year: Letter Writing and the Mails in the Canadas, I640-1830 (Waterloo: Wilfred Laurier University Press, 1997).

I6 See Ross Harvey, 'The Power of the Press in Colonial New Zealand,' Papers of the Bibliographical Societies of Australia and New Zealand, 20 no. 2 (1996), I33.

I7 James Reid to Thomas Gibson (January I 849), Archives of Ontario: MU 2382. It is possible that Reid purchased the books he mentions in Canada. Local Scottish newspapers would of course have been more difficult to acquire.

I8 Cattermole, Advantages of Emigration [quoted in Mathison, ro7]. Luggage allowance could vary widely: on the Shaw, Saville, \& Albion Line to New Zealand in the I860s, 'Every passenger in the first and second class was allowed half a ton measurement of luggage free of charge and in the steerage, a quarter of a ton [560 lb.] Anything in excess of this had to be paid for at a fairly steep price.' [See Frank Bowen, The Flag of the Southern Cross (n.d.), 23].

I9 Minutes of the Committee on Emigration from the West of Scotland to His Majesty's Settlements in Upper Canada, March I82I, quoted in Lamond, $A$ Narrative, 40.

20 Journal of a voyage from Glasgow to New York. National Archives of Canada: MG 24 I I 97.

2 I Emigrants' Letters: Being a Collection of Recent Communications from Settlers in the British Colonies (London, I85o), I 23.

22 Otago Journal, May 1848, 30-3 I.

23 One passenger reported to relatives that 'the congregational library was opened once a week, when books were returned and new ones issued' (Otago Journal, 42 ). In his shipboard journal the expedition's leader, Reverend Thomas Burns, dutifully records on February I, I 848: 'Issued from box No. 7 one volume of the Congl. Library to each mess'. [Rev Thomas Burns, Shipboard Diary, m s Otago Settlers Museum]. From a diary kept by another passenger we learn that a mess on board the Philip Laing constituted at least one male adult and four or five others. Thus was there provided one book per week between six passengers. 
24 National Archives of Canada: M G 24 I 197. Another solution to the scarcity of print on board ship was the occasional publication of a shipboard newspaper. Detailed research on Australian shipboard newspapers, of which several examples survive, is currently being undertaken by Des Cowley and Shona Dewar at the La Trobe Library, Melbourne. Passengers on board the Philip Laing we know had access to two manuscript newspapers, one published weekly 'by a cabin passenger ... another by a steerage passenger as often'. (Otago Journal, 42).

25 Benedict Anderson, Imagined Communities: Reflections on the Origin and Spread of Nationalism (London: Verso, 1991), 72.

26 Elleke Boehmer, Colonial and Postcolonial Literature (Oxford University Press, I995), I3, 52 .

27 Charles Tilly 'Transplanted Networks', Immigration Reconsidered, Virginia Yans-McLaughlin ed. (Oxford University Press, I 990), 87.

28 Tilly, 'Transplanted Networks', 89.

29 The amount of archival material for the study of missionary publishing and printing for Canada alone is vast. Thanks to Leslie Howsam's work on the British and Foreign Bible Society, John Wiseman's work on the distribution of nineteenth-century missionary literature in Ontario, and John Moir's edition of the papers of the Glasgow Colonial Society, we are beginning to understand how these print networks were actually created and functioned on a daily basis.

30 George Parker has drawn attention to the case of Walter Johnstone, who reported to the Scottish Missionary Society that he found at the Charlottetown Despository no Psalms bound in with the Bibles, 'a sorry state of affairs for Scottish Christians'. [The Beginnings of the Book Trade in Canada (Toronto University Press, 1985), I9.] A helpful account of the book exporting activities of one of the most active religious organization is provided in John S. Moir, 'Through Missionary Eyes: The Glasgow Colonial Society and the Immigrant Experience in British North America', The Immigrant Experience, C. Kerrigan ed. (Guelph, I989), 95-ro9.

3I Diary of Rev James Nisbet, I 848. National Archives of Canada: M G2 4J2S.

32 Quoted in Don Watson, Caledonia Australis: Scottish Highlanders on the Frontier of Australia (Sydney: Collins, 1984), 66.

33 Maureen Molloy, Those who Speak to the Heart: The Nova Scotian Scots at Waipu I 854-1920 (Palmerston North: Dunmore, I98), I 26.

34 See Carol McGuirk, 'Burns and Nostalgia', Burns Now, Kenneth Simpson ed. (Edinburgh: Canongate Academic, 1994), 3 I-69.

35 An analysis of imprints where place of origin can be determined demonstrates that a clear majority of the Waipu books were produced in Scotland (60), compared to 32 produced in England (though a number of these are in Gaelic. Although the community's principle spoken language was for many years Gaelic, most of its reading appears to have been, by necessity, in English. A high proportion of the Normanites devotional, and therefore most prized, books were in the native language). 9 titles originate in North America, and only 3 in New Zealand.

36 Cathy Davidson, Revolution and the Word (Oxford University Press, I986), 72. 
37 Carl Klinck, Literary History of Canada and edition, volume one (University of Toronto Press, 1976), 254.

38 Quoted in DCB, vII, 920.

39 Olive and Sydney Checkland, Industry and Ethos: Scotland I832-1914 (Edinburgh University Press, I989), I 58.

40 Wilfred Egglestone, The Frontier and Canadian Letters (Toronto: McClelland and Stewart, 1957), 56, 33 .

4I For the first sustained treatment of book trade links between Britain and Canada, see George Parker, The Beginnings of the Book Trade in Canada. More recent developments include Fiona Black on Scottish books in Canada [see, for example, 'Newspapers as primary sources in Canadian-Scottish book trade history': the example of Halifax, Nova Scotia, I752-I820', Epilogue Io (I995), 43-5 I; 'A Scottish element in Canadian print culture: some preliminary questions on definition and evidence', Eighteenth-Century Scotland, ro (I996), I I-I4; and 'Advent'rous merchants and Atlantic waves': a preliminary study of the Scottish contribution to book availability in Halifax, Nova Scotia, I752-I8IO' in Myth, Migration and the Making of Memory: Scotia and Nova Scotia, I700-I990, Michael Vance and Marjorie Harper, eds. (Fredericton: Acadiensis Press, forthcoming|l, Bertrum MacDonald's work on the Scottish Nova Scotian bookseller James Dawson, and John Wiseman's investigation of Ontario missionaries [see 'Bible and Tract Disseminating', Publishing History i 8: 1985, 69-83; also 'Silent Companions: the Dissemination of Books and Periodicals in Nineteenth-Century Ontario', Publishing History I2: 1982, 17-50]. For a more wide-ranging consideration of the connections between the history of the book and colonial cultural history, see I.R. Willison, 'Across Boundaries: the History of the Book and National and International Literatures in English', in Across Boundaries: The Book in Commerce and Culture, B. Bell, J. Bevan, and P. Bennet, eds., (Newcastle, Delaware: Oak Knoll, forthcoming|. 